\title{
Radioiodinated somatostatin analogue RC-160: preparation, biological activity, in vivo application in rats and comparison with $\left[{ }^{123} \mathrm{I}-\mathrm{Tyr}^{3}\right]$ octreotide
}

\author{
W.A.P. Breeman ${ }^{1}$, L.J. Hofland², W.H. Bakker ${ }^{1}$, M. van der Pluijm¹, P.M. van Koetsveld², M. de Jong ${ }^{1}$, \\ B. Setyono-Han', D.J. Kwekkeboom¹, T.J. Visser², S.W.J. Lamberts², E.P. Krenning ${ }^{1,2}$ \\ ${ }^{1}$ Department of Nuclear Medicine, University Hospital Dijkzigt, Rotterdam, The Netherlands \\ 2 Department of Internal Medicine III, University Hospital Dijkzigt, Rotterdam, The Netherlands \\ ${ }^{3}$ Dr. Daniël den Hoed Cancer Centre, Rotterdam, The Netherlands
}

Received 1 March and in revised form 20 June 1993

\begin{abstract}
We have evaluated the potential usefulness of the radioiodinated octapeptide $\mathrm{RC}-160$, a somatostatin analogue, which might serve as a radiopharmaceutical for the in vivo detection of somatostatin receptorpositive tumours. For this purpose, iodine- 123 and iodine-125 labelled RC-160 was tested for biological activity and applied in vivo in rats bearing the transplantable rat pancreatic tumour CA20948, which expresses somatostatin receptors. Our group has recently described the in vivo visualization of such tumours in rats and in humans with the radioiodinated somatostatin analogue $\left[\mathrm{Tyr}^{3}\right]$ octreotide. Like $\left[{ }^{123} \mathrm{I}-\mathrm{Tyr}^{3}\right]$ octreotide, ${ }^{123} \mathrm{I}$ RC-160 showed uptake in and specific binding in vivo to somatostatin receptor-positive organs and tumours. However, blood radioactivity (background) was higher, resulting in a lower tumour to blood (background) ratio. We therefore conclude that in this animal model ${ }^{123}$ I$\mathrm{RC}-160$ has no advantage over $\left[{ }^{123} \mathrm{I}-\mathrm{Tyr}^{3}\right]$ octreotide as a radiopharmaceutical for the in vivo use as a somatostatin receptor imager, although, like $\left.{ }^{123} \mathrm{I}-\mathrm{Tyr}^{3}\right]$ octreotide, ${ }^{123}$ I-RC- 160 shows specific binding to different somatostatin receptor-positive organs. Recently differences were reported in affinity between somatostatin and its analogues for somatostatin receptors expressed in different human cancers, like those of the breast, ovary, exocrine pancreas, prostate and colon. Therefore ${ }^{123}$ I-RC-160 might be of interest for future use in humans as a radiopharmaceutical for imaging octreotide receptor-negative tumours.
\end{abstract}

Key words: Radioiodinated RC-160 - Somatostatin Specific binding - Tumour imager - Peptide

Eur J Nucl Med (1993) 20:1089-1094

Correspondence to: W.A.P. Breeman, Department of Nuclear Medicine, University Hospital Dijkzigt, Dr. Molewaterplein 40, NL-3015 GD Rotterdam, The Netherlands

\section{Introduction}

High numbers of high-affinity somatostatin receptors for both native somatostatin (for structure, see Fig.1) and the synthetic octapeptide octreotide (Sandostatin) have been detected on most endocrine tumours, such as endocrine pancreatic tumours and carcinoids [1-4]. We have recently described the visualization of somatostatin receptor-positive tumours in vivo after the intravenous administration of $\left.{ }^{[23} \mathrm{I}-\mathrm{Tyr}^{3}\right]$ octreotide [5-9], and these results have been confirmed by others [10-12]. Radioiodinated $\left[\mathrm{Tyr}^{3}\right.$ ]octreotide is frequently used for the in vitro determination of the presence of somatostatin receptors [13]. Recently, several reports have been published on the in vitro binding to somatostatin receptors of another somatostatin analogue, the octapeptide $\mathrm{RC}-160$ [14-16]. It has been reported that $\mathrm{RC}-160$ has a higher affinity than octreotide for the somatostatin receptor in human breast, ovarian, exocrine pancreatic, prostatic and colonic cancers [14-16]. A phase 1 clinical trial with RC-160 in patients with advanced exocrine pancreatic cancer is being performed, and it appears that $\mathrm{RC}-160$ is well tolerated at doses up to $1500 \mu \mathrm{g} /$ day $[17,18]$. The possibility of RC-160 binding to a somatostatin receptor subtype on human exocrine pancreatic adenocarcinoma, which does not bind octreotide [19], offers a potential advantage for RC-160 over octreotide as a radiolabelled tumour tracer. RC-160 may, in contrast to octreotide [20], also pass the blood-brain barrier [21]. This could represent a benefit in visualizing somatostatin receptor-positive brain tumours with an intact blood-brain barrier. We investigated radioiodinated RC-160 (for structure, see Fig. 1) for potential use in scintigraphy in normal rats and in rats bearing the transplantable pancreatic somatostatin receptor-positive tumour CA20948 [13, 19, 22]. A comparison was made with $\left[{ }^{123}\left[-T_{y r}{ }^{3}\right]\right.$ octreotide, and the possible additional value of ${ }^{123}$ I-RC-160 as a radiopharmaceutical was evaluated. 
Somatostatin

Ala-Gly-Cys-Lys-Asn-Phe-Phe-Trp-Lys-Thr-Phe-Thr-Ser-Cys

Octreotide

D-Phe-Cys-Phe-D-Trp-Lys-Thr-Cys-Thr(ol)

$\left[{ }^{123} \mathrm{I}-\mathrm{Tyr}^{3}\right]$ octreotide

H-D-Phe-Cys-Tyr-D-Trp-Lys-Thr-Cys-Thr(ol)

${ }^{123} \mathrm{I}-\mathrm{RC}-160$

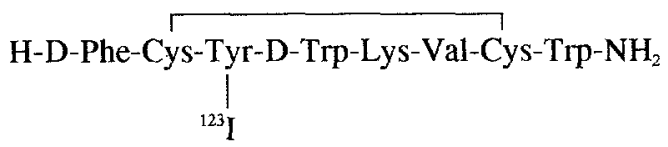

Fig. 1. Stuctural formulae of native somatostatin, octreotide, $\left[{ }^{123} \mathrm{I}-\right.$ $\left.\mathrm{Tyr}^{3}\right]$ octreotide and ${ }^{123} \mathrm{I}-\mathrm{RC}-160$. In $\left[\mathrm{Tyr}^{3}\right]$ octreotide the amino acid Tyr replaces Phe to make radioiodination possible. In RC-160 Tyr is naturally present

\section{Materials and methods}

Radiopharmaceuticals. RC-160 was obtained from Peninsula Laboratories (Belmont, Calif, USA). Radioiodination and purification was performed using the technique described by Bakker [6].

$\left[\mathrm{Tyr}^{3}\right]$ octreotide and $\mathrm{RC}-160$ were labelled with ${ }^{123} \mathrm{I}$ - (specific activity $3.7 \mathrm{TBq}{ }^{123} \mathrm{I}-/ \mathrm{mg}$, Medgenix, Belgium) and ${ }^{125} \mathrm{I}$ (specific activity $0.62 \mathrm{TBq}^{125} \mathrm{I} / \mathrm{mg}$, Amersham, UK). For the in vivo studies we used the somatostatin analogues labelled with ${ }^{123} \mathrm{I}$. The in vitro binding studies were performed with (HPLC)-high-performance liquid chromatography purified mono-iodinated somatostatin analogues, since carrier-free radioligands are required for these assays. The radioiodination was carried out by adding $2.5 \mu \mathrm{g} \mathrm{RC}-$ 160 in $35 \mu 10.05 M$ acetic acid and $1.6 \mu \mathrm{g}$ chloramine-T in 20 $\mu l 0.05 M$ phosphate buffer (pH 7.5) to $200 \mathrm{MBq}(\approx 60 \mu \mathrm{l}){ }^{123} \mathrm{I}$ or $80 \mathrm{MBq}(20 \mu \mathrm{I})^{125} \mathrm{I}$ in the form of sodium iodide. The reaction was started by the addition of chloramine-T, representing an only 2.5-fold molar excess over peptide in order to prevent oxidation of the disulphide-bridge of RC-160. The mixture was then vortexed for $1 \mathrm{~min}$. The radioiodination was stopped by adding $1 \mathrm{ml}$ $10 \%$ human serum albumin (Merieux, Lyon, France). After vortexing for $30 \mathrm{~s}, 20 \mathrm{ml} 5 \mathrm{mM}$ ammonium acetate was added. Pu- rification was performed using a SEP-PAK $\mathrm{C}_{18}$ reversed-phase extraction cartridge (Waters Associates, Milford, Mass., USA), which was washed with $5 \mathrm{ml} \mathrm{70 \%} \mathrm{ethanol,} 5 \mathrm{ml}$ 2-propanol and $5 \mathrm{ml}$ distilled water. After application of the sample, the SEP-PAK cartridge was washed with $5 \mathrm{ml}$ distilled water and radioiodinated RC-160 was eluted with $5 \mathrm{ml} 96 \%$ ethanol. The solvent was evaporated at $40^{\circ} \mathrm{C}$ under a gentle stream of nitrogen. The residue (approximately $0.5 \mathrm{ml}$ ) was diluted with $2.5 \mathrm{ml} 154 \mathrm{~m} M \mathrm{NaCl}$ and $0.05 M$ acetic acid ( $\mathrm{pH} 3)$, and the mixture was passed through a low protein-binding $0.22-\mu \mathrm{m}$ Millex-GV filter (Millipore, Milford, Mass., USA). The labelling of [ $\left.\mathrm{Tyr}^{3}\right]$ octreotide and the measurements of radioactivity in all fractions were carried out as described previously [6]. The ${ }^{123}$ I-labelled somatostatin analogues for in vivo use were not purified by HPLC and, hence, consisted of mixtures of mono- and di-radioiodinated and noniodinated peptides (see Results, Radiolabelling of $R C-160$ ). All chemicals used were of the highest purity available.

Biological activity. The biological activity of HPLC-purified mono- ${ }^{125} \mathrm{I}-\mathrm{RC}-160$ and $\left[{ }^{125} \mathrm{I}-\mathrm{Tyr}^{3}\right]$ octreotide was assessed by measuring their potency to inhibit the secretion of rat growth hormone $(\mathrm{rGH})$ from cultured rat pituitary cells as described previously [23].

Animals and tumours. Twenty-four male Lewis rats $(250-300 \mathrm{~g})$ were inoculated in both upper hind legs with the transplantable rat pancreatic tumour CA20948, which has previously been shown to possess somatostatin receptors [19]. Sixteen male Lewis rats $(250-300 \mathrm{~g})$ without tumour were used as controls. The rats were anaesthetized with ether. The radiopharmaceuticals were injected into the dorsal vein of the penis, using siliconized syringes (Sigmacoat, Sigma, St. Louis, Mo., USA). The dose was 18.5 MBq $(0.5 \mu \mathrm{g})$ for the ${ }^{123} \mathrm{I}$-analogue. The radioactivity of the syringes was measured in a dose calibrator (VDC-202, Veenstra, Joure, The Netherlands) in a standard geometry before and after the injection.

In order to study the organ distribution of ${ }^{123} \mathrm{I}-\mathrm{RC}-160$ and $\left[{ }^{123} \mathrm{I}-\mathrm{Tyr}^{3}\right]$ octreotide in the 16 control rats, the rats were allocated to two groups for each radiopharmaceutical. Four rats were injected subcutaneously between the scapulae with $\mathrm{ml} 0.01 \mathrm{M}$ acetic acid containing $154 \mathrm{mM} \mathrm{NaCl}$, and four other rats were injected with $1 \mathrm{mg} \mathrm{RC}-160$ in the same solvent in order to saturate the somatostatin receptors. Forty-five minutes later the rats were injected with ${ }^{123}$ I-RC-160. Similarly, the two other groups of four rats were pretreated with vehicle or $1 \mathrm{mg}$ octreotide and were subsequently injected intravenously with $\left[{ }^{123} \mathrm{I}-\mathrm{Tyr}^{3}\right]$ octreotide. The rats were killed $4 \mathrm{~h}$ after administration of ${ }^{123} \mathrm{I}-\mathrm{RC}-160$ or $\left[{ }^{123} \mathrm{I}-\mathrm{Tyr}^{3}\right]$ octreotide.

The 24 tumour-bearing Lewis rats were divided into three groups of eight rats. In each group four rats were injected subcutaneously with $1 \mathrm{mg} \mathrm{RC}-160$ in order to saturate the somatostatin receptor, as mentioned above. The three groups of eight rats were killed at $30 \mathrm{~min}, 4 \mathrm{~h}$ or $24 \mathrm{~h}$ after administration of ${ }^{123}$ I-RC-160. The radioactivity concentration in various tissues was subsequently measured.

The specific binding was defined as the difference between the individual uptake in the non-saturated tissues and the mean uptake in the saturated tissues, which are expressed as percentages of the injected radioactivity per gram tissue in the respective organs (mean $\pm \mathrm{SD}$ ) after administration of ${ }^{123} \mathrm{I}-\mathrm{RC}-160$ or $\left[{ }^{123} \mathrm{I}-\right.$ $\mathrm{Tyr}^{3}$ ] octreotide.

Data acquisition and statistical analysis. All results are expressed as the mean $\pm \mathrm{SD}$. Tissue-binding values and effects on rat growth 
hormone secretion for both radiolabelled peptides were evaluated using Student's $t$-test. A $P$ value of $<0.05$ was considered significant. The tissue distribution and metabolism of ${ }^{123} \mathrm{I}-\mathrm{RC}-160$ and $\left[{ }^{123} \mathrm{I}_{-\mathrm{Tyr}^{3}}\right]$ octreotide in vivo were studied by gamma camera (Rota-II, Siemens) scintigraphy and measurement of isolated organs in a LKB-1282-Compugammasystem [6]. The radioactivity in blood and urine was analysed as described previously [6].

\section{Results}

\section{Radiolabelling of RC-160}

The efficiency of labelling of RC-160 was $40 \%-60 \%$ for ${ }^{125} \mathrm{I}$ and $70 \%-90 \%$ for ${ }^{123} \mathrm{I}$, in agreement with the radioiodination data for $\left[\mathrm{Tyr}^{3}\right]$ octreotide, as described previously [6]. Purification of the iodination mixture using the SEP-PAK $\mathrm{C}_{18}$ reversed-phase cartridge resulted in mainly non-peptide-bound radioiodine in the water fraction and more than $99 \%$ peptide-bound radioiodine in the ethanol fraction, revealed by HPLC. In Fig. 2 a typical HPLC elution pattern of the peptides eluted in the ethanol fraction is show, indicating a radiochemical purity of more than $95 \%$ of mono-radioiodinated RC160. The simultaneously measured absorbance at 254 $\mathrm{nm}$ and radioactivity show a clear separation between radioiodinated RC-160 and non-radioiodinated RC- 160 .

The acetic acid wash, included in the SEP-PAK purification of $\left[{ }^{123}\left[-\mathrm{Tyr}^{3}\right]\right.$ octreotide, was omitted from the isolation procedure for ${ }^{123}$ I-RC-160, since this wash was found already to contain a substantial fraction $(\approx 5 \%-$ $10 \%$ ) of the radioiodinated $\mathrm{RC}-160$, while only negligible amounts of free radioiodide were detected.

Since the radiolabelling and the SEP-PAK $\mathrm{C}_{18}$ separation technique appeared adequate (more than $95 \%$ radiochemical purity of mono-radioiodinated $\left[\mathrm{Tyr}^{3}\right] \mathrm{oc}-$ treotide and RC-160), HPLC purification of the radiolabelled somatostatin analogues was not performed. These results were in agreement with the radiolabelling results of $\left[\mathrm{Tyr}^{3}\right]$ octreotide [6].

\section{Receptor binding and specific biological activity}

Table 1 shows the effects of ${ }^{125} \mathrm{I}-\mathrm{RC}-160$ and $\left[{ }^{125} \mathrm{I}-\right.$ $\mathrm{Tyr}^{3}$ ]octreotide on the secretion of $\mathrm{rGH}$ by cultured rat pituitary cells. Both iodinated somatostatin analogues significantly inhibited rGH secretion at $1 \mathrm{n} M$. Both radioiodinated analogues caused a similar dose-response as the non-radioiodinated counterparts (data not shown).

\section{Animal studies}

Dynamic scintigraphy of tumour-bearing and control rats after i.v. administration of ${ }^{123} \mathrm{I}-\mathrm{RC}-160$ and $\left[{ }^{123} \mathrm{I}-\right.$ $\left.\mathrm{Tyr}^{3}\right]$ octreotide showed a fast disappearance of the radioactivity from the circulation. With both radioiodinated analogues radioactivity in the blood circulation,

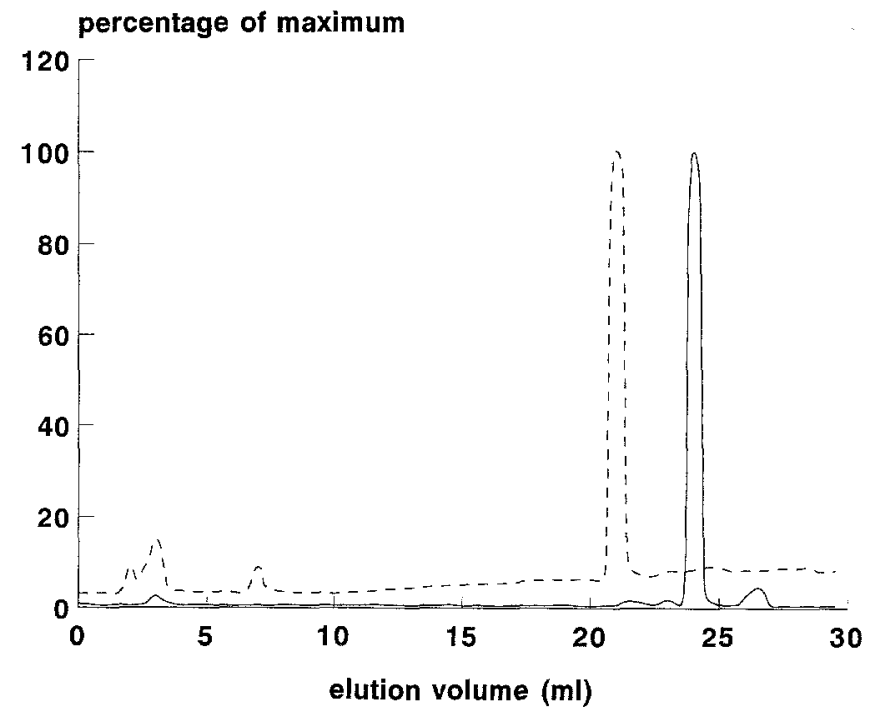

Fig. 2. HPLC-elution pattern of the ethanol fraction of SEP-PAK $\mathrm{C}_{18}$ purification. Non-radioiodinated RC-160 is measured by UV absorbance ( $\lambda=254 \mathrm{~nm}$, broken line), radioiodinated $\mathrm{RC}-160$ and free radioiodide by gamma detection (solid line). The gamma detected peak at $27 \mathrm{~min}$ is the di-iodinated compound

Table 1. Effects of ${ }^{125} \mathrm{I}-\mathrm{RC}-160$ and $\left[{ }^{125} \mathrm{I}-\mathrm{Tyr}{ }^{3}\right]$ octreotide on secretion of rGH from cultured rat pituitary cells $(n=4)$

\begin{tabular}{lll}
\hline Peptide & $\begin{array}{l}\text { Concentration } \\
(\mathrm{n} M)\end{array}$ & $\begin{array}{l}\mathrm{rGH} \\
(\mathrm{ng} / \mathrm{ml} \pm \mathrm{SD})(\%)\end{array}$ \\
\hline Control & & $89.1 \pm 9.0(100)$ \\
${ }^{125} \mathrm{I}-\mathrm{RC}-160$ & 0.01 & $91.7 \pm 4.6(103)$ \\
& 0.1 & $95.5 \pm 3.0(107)$ \\
& 1 & $77.2 \pm 11.1(87)^{*}$ \\
$\left.{ }^{125}{ }^{1-T y r^{3}}\right]$ octreotide & 0.01 & $90.0 \pm 4.8(101)$ \\
& 0.1 & $79.9 \pm 11.3(90)$ \\
& 1 & $64.8 \pm 4.6(73)^{*}$ \\
\hline
\end{tabular}

${ }^{*} P<0.05$ vs control

as measured above the heart with the gamma camera, decreased in less than 2 min to $50 \%$ of the highest measured radioactivity. This rapid fall in the blood activity can be explained by the phenomenon of distribution of the activity over the whole blood and the interstitial space.

Thirty minutes after injection static images showed a clear uptake of radioactivity in the liver and intestines. The left kidney was seen, as well as excreted activity in the urinary bladder. The right kidney was overprojected by the liver.

Dynamic tumour uptake in situ in the rat during the first 30 min after injection of ${ }^{123}$ I-RC-160 was analysed with the gamma camera. After background correction, using adjacent tissue as reference, no increased uptake in the tumour was found, whereas specific binding in the isolated tumour became statistically significant at 4 h (Table 2). As can be seen in Table 2, there was sig- 
Table 2. Tissue distribution (\% of injected dose/g tissue) and specific binding $(\Delta)$ of ${ }^{123} \mathrm{I}-\mathrm{RC}-160$ in tumour-bearing rats after intravenous administration (mean $\pm \mathrm{SD})^{\mathrm{a}}$

\begin{tabular}{|c|c|c|c|c|c|}
\hline \multirow{2}{*}{ Tissue } & & 0.5 h p.i. & 4 h p.i. & \multicolumn{2}{|c|}{24 h p.i. } \\
\hline & - & $0.91 \pm 0.38$ & $0.32 \pm 0.08$ & 0.06 & \pm 0.02 \\
\hline & + & $0.10 \pm 0.01$ & $0.07 \pm 0.02$ & 0.021 & \pm 0.002 \\
\hline & $\Delta$ & $0.81 \pm 0.38^{*}$ & $0.25 \pm 0.08^{*}$ & 0.040 & $\pm 0.019^{*}$ \\
\hline \multirow[t]{3}{*}{ Adrenals } & - & $1.17 \pm 0.06$ & $0.54 \pm 0.09$ & 0.06 & \pm 0.03 \\
\hline & + & $0.20 \pm 0.06$ & $0.07 \pm 0.01$ & 0.038 & \pm 0.009 \\
\hline & $\Delta$ & $0.97 \pm 0.06^{*}$ & $0.47 \pm 0.09^{*}$ & 0.022 & \pm 0.028 \\
\hline \multirow[t]{3}{*}{ Pituitary } & - & $0.16 \pm 0.06$ & $0.08 \pm 0.02$ & 0.05 & \pm 0.05 \\
\hline & + & $0.021 \pm 0.003$ & $0.013 \pm 0.002$ & 0.004 & \pm 0.000 \\
\hline & $\Delta$ & $0.13 \pm 0.06^{*}$ & $0.064 \pm 0.020^{*}$ & 0.044 & \pm 0.048 \\
\hline \multirow{3}{*}{$\begin{array}{l}\text { Brain } \\
\text { cortex }\end{array}$} & - & $0.014 \pm 0.002$ & $0.008 \pm 0.002$ & 0.0019 & \pm 0.0009 \\
\hline & + & $0.008 \pm 0.001$ & $0.003 \pm 0.000$ & 0.0013 & \pm 0.0003 \\
\hline & $\Delta$ & $0.007 \pm 0.003^{*}$ & $0.005 \pm 0.002^{*}$ & 0.0006 & \pm 0.0009 \\
\hline \multirow[t]{3}{*}{ Tumour } & - & $0.23 \pm 0.07$ & $0.20 \pm 0.05$ & 0.037 & \pm 0.021 \\
\hline & + & $0.11 \pm 0.02$ & $0.08 \pm 0.02$ & 0.036 & \pm 0.003 \\
\hline & $\Delta$ & $0.11 \pm 0.07$ & $0.12 \pm 0.05^{*}$ & 0.001 & \pm 0.021 \\
\hline \multirow[t]{3}{*}{ Kidneys } & - & $0.74 \pm 0.13$ & $0.43 \pm 0.13$ & 0.11 & \pm 0.03 \\
\hline & + & $0.53 \pm 0.04$ & $0.22 \pm 0.05$ & 0.10 & \pm 0.02 \\
\hline & $\Delta$ & $0.21 \pm 0.13$ & $0.21 \pm 0.13$ & 0.01 & \pm 0.03 \\
\hline
\end{tabular}

${ }^{*} P<0.01$, specific binding significantly different from zero

${ }^{a}$ Each group contained four rats: -, no pretreatment; +, pretreatment with $1 \mathrm{mg}$ unlabelled RC-160 subcutaneously 45 min prior to the injection of ${ }^{123} \mathrm{I}-\mathrm{RC}-160$

Table 3. Tissue distribution [with $(+)$ and without $(-)$ pretreatment of rats with unlabelled RC-160] and specific binding $(\Delta)$ in somatostatin receptor-positive organs (mean \pm SD) in non-tumour-bearing rats $(n=4), 4 \mathrm{~h}$ after injection of ${ }^{123} \mathrm{I}-\mathrm{RC}-160$. The rats in the parallel experiment with $\left[{ }^{123} \mathrm{I}^{-\mathrm{Tyr}^{3}}\right]$ octretide were pretreated with $1 \mathrm{mg}$ octreotide

\begin{tabular}{|c|c|c|c|c|c|}
\hline Tissue & & \multicolumn{2}{|c|}{$123 I-R C-160$} & \multicolumn{2}{|c|}{$\left[{ }^{123} \mathrm{I}-\mathrm{Tyr}^{3}\right]$ octreotide } \\
\hline Pancreas & $\begin{array}{l}- \\
+ \\
\Delta\end{array}$ & $\begin{array}{l}0.21 \\
0.025 \\
0.17\end{array}$ & $\begin{array}{l} \pm 0.05^{*} \\
\pm 0.006 \\
\pm 0.05^{* * *}\end{array}$ & $\begin{array}{l}1.03 \\
0.023 \\
1.01\end{array}$ & $\begin{array}{l} \pm 0.15 \\
\pm 0.002 \\
\pm 0.15^{* *}\end{array}$ \\
\hline Adrenals & $\begin{array}{l}- \\
+ \\
\Delta\end{array}$ & $\begin{array}{l}0.19 \\
0.042 \\
0.15\end{array}$ & $\begin{array}{l} \pm 0.03^{*} \\
\pm 0.010 \\
\pm 0.03^{* * * *}\end{array}$ & $\begin{array}{l}0.26 \\
0.027 \\
0.23\end{array}$ & $\begin{array}{l} \pm 0.02 \\
\pm 0.002 \\
\pm 0.02^{\text {* }}\end{array}$ \\
\hline Pituitary & $\begin{array}{l}- \\
+ \\
\Delta\end{array}$ & $\begin{array}{l}0.066 \\
0.0078 \\
0.063\end{array}$ & $\begin{array}{l} \pm 0.007^{*} \\
\pm 0.0020 \\
\pm 0.007^{* *}\end{array}$ & $\begin{array}{l}0.32 \\
0.0067 \\
0.31\end{array}$ & $\begin{array}{l} \pm 0.09 \\
\pm 0.001 \\
\pm 0.09^{* *}\end{array}$ \\
\hline $\begin{array}{l}\text { Brain } \\
\text { cortex }\end{array}$ & $\begin{array}{l}- \\
+ \\
\Delta\end{array}$ & $\begin{array}{l}0.005 \\
0.001 \\
0.003\end{array}$ & $\begin{array}{l} \pm 0.0014^{*} \\
\pm 0.0003 \\
\pm 0.0014^{* * *}\end{array}$ & $\begin{array}{l}0.0019 \\
0.0012 \\
0.0007\end{array}$ & $\begin{array}{l} \pm 0.0002 \\
\pm 0.0002 \\
\pm 0.0002\end{array}$ \\
\hline
\end{tabular}

${ }^{*} P<0.01,{ }^{123} \mathrm{I}-\mathrm{RC}-160$ vs $\left[{ }^{123} \mathrm{I}-\mathrm{Tyr}{ }^{3}\right]$ octreotide

** $P<0.01$, specific binding significantly different from zero
Table 4. Tissue distribution (\% of injected dose/g tissue, mean $\pm \mathrm{SD})$ in tumour-bearing rats $(n=4) 24 \mathrm{~h}$ after intravenous injection of $0.5 \mu \mathrm{g}$ radioiodinated somatostatin analogue

\begin{tabular}{|c|c|c|c|c|}
\hline \multirow{2}{*}{$\begin{array}{l}\text { Tissue } \\
\text { Spleen }\end{array}$} & \multicolumn{2}{|c|}{${ }^{123} \mathrm{I}-\mathrm{RC}-160$} & \multicolumn{2}{|c|}{$\left[{ }^{123}\left[-\mathrm{Tyr}^{3}\right]\right.$ octreotide } \\
\hline & 0.06 & \pm 0.03 & 0.028 & \pm 0.021 \\
\hline Kidneys & 0.12 & \pm 0.03 & 0.13 & \pm 0.01 \\
\hline Liver & 0.17 & $\pm 0.03^{*}$ & 0.027 & \pm 0.005 \\
\hline Intestines & 0.2 & $\pm 0.0^{*}$ & 0.03 & \pm 0.01 \\
\hline Thyroid & 320 & \pm 70 & 180 & \pm 50 \\
\hline Thymus & 0.068 & $\pm 0.032^{*}$ & 0.016 & \pm 0.007 \\
\hline Lungs & 0.12 & $\pm 0.04^{*}$ & 0.033 & \pm 0.006 \\
\hline Blood & 0.13 & $\pm 0.08^{*}$ & 0.006 & \pm 0.000 \\
\hline Pancreas & 0.06 & \pm 0.02 & 0.11 & \pm 0.04 \\
\hline Adrenals & 0.06 & \pm 0.03 & 0.04 & \pm 0.01 \\
\hline Pituitary & 0.05 & $\pm 0.05^{*}$ & 0.17 & \pm 0.02 \\
\hline Brain cortex & 0.0019 & \pm 0.0009 & 0.002 & \pm 0.001 \\
\hline Tumour & 0.037 & $\pm 0.021^{*}$ & 0.007 & \pm 0.001 \\
\hline
\end{tabular}

${ }^{*} P<0.01,{ }^{123} \mathrm{I}-\mathrm{RC}-160$ vs $\left[{ }^{123} \mathrm{I}-\mathrm{Tyr}^{3}\right]$ octreotide

nificant specific binding in all the somatostatin receptor- positive tissues analysed, i.e. pancreas, adrenals, pituitary and brain cortex, at 0.5 and $4 \mathrm{~h}$, and in the tumour at $4 \mathrm{~h}$ after injection. After $24 \mathrm{~h}$ there was still significant specific binding in the pancreas. From 30 min after the administration of ${ }^{123}$ I-RC-160, total radioactivity disappeared rapidly from the measured organs and tumours. Statistically significant specific binding was still present $24 \mathrm{~h}$ after [ ${ }^{123} \mathrm{I}-\mathrm{Tyr}^{3}$ ]octreotide injection in the pancreas, adrenal and pituitary gland (data not shown).

In Table 3 the tissue distributions, $4 \mathrm{~h}$ after injection, are compared between pretreated and non-pretreated, non-tumour-bearing rats. We found a higher uptake of $\left[{ }^{123} \mathrm{I}-\mathrm{Tyr}^{3}\right]$ octreotide in the adrenals, the pancreas and the pituitary gland, than was found when using ${ }^{123}$ I-RC- 160 . The effect of pretreatment with unlabelled $\mathrm{RC}-160$ or octreotide is evident in the somatostatin receptor-positive organs for both ${ }^{123} \mathrm{I}-\mathrm{RC}-160$ and ${ }_{\left[{ }^{123} \mathrm{I}-\mathrm{Tyr}^{3}\right] \text { octreo- }}$ tide. Significantly higher specific binding of radioactivity was found after administration of ${ }^{123}\left[-\right.$ Tyr $\left.^{3}\right]$ octreotide in the adrenals, the pancreas and the pituitary gland than after administration of ${ }^{123} \mathrm{I}-\mathrm{RC}-160$. In the rat brain cortex ${ }^{123}$ I-RC-160 has a higher uptake and specific binding than $\left[{ }^{123} \mathrm{I}-\mathrm{Tyr}^{3}\right]$ octreotide.

Urine samples were obtained $30 \mathrm{~min}$ p.i. from tumour-bearing rats $(n=4)$, showing $13 \% \pm 1 \%$ of the total radioactivity in the form of peptide-bound radioiodine. Twenty-four hours p.i. the percentage of peptide-bound radioiodine in urine and blood had dropped to $1.3 \% \pm$ $0.2 \%$ and $1.1 \% \pm 0.3 \%$, respectively, and more than $95 \%$ of the radioactivity in the urine was free radioiodine, which is comparable with the results obtained using $\left[{ }^{123} \mathrm{I}-\mathrm{Tyr}^{3}\right]$ octreotide as radioligand (data not shown).

A comparison of the tissue radioactivity concentrations $24 \mathrm{~h}$ after injection of ${ }^{123}$ I-RC-160 and $\left[{ }^{123} \mathrm{I}-\right.$ $\left.\mathrm{Tyr}^{3}\right]$ octreotide is presented in Table $\left.4 .{ }^{123}{ }^{12}-\mathrm{Tyr}^{3}\right]$ octreo- 
tide had a higher clearance of radioactivity from somatostatin receptor-negative tissues, such as liver, thymus, blood and lungs, and a significantly higher binding in the somatostatin receptor-positive pituitary than ${ }^{123} \mathrm{I}-\mathrm{RC}$ 160. Only in the tumour was there significantly higher binding of radioactivity for ${ }^{123}$ I-RC-160 compared to ${ }^{[23}\left[-\mathrm{Tyr}^{3}\right]$ octreotide, but as can be seen from Table 2, this was not specific binding.

\section{Discussion}

RC-160 is, like octreotide, a somatostatin analogue with potent hormone secretion-inhibiting characteristics in vivo and in vitro. However, discrepancies with octreotide have been described, especially with regard to binding to a number of human cancers, like those of the breast, ovary, exocrine pancreas, prostate and colon [14-18, 21]. Therefore, radioiodinated RC-160 might be an important radiopharmaceutical, having potential advantages over radioiodinated octreotide for the in vivo detection of the aforementioned somatostatin receptorpositive tumours. In the literature no data are available on tissue distribution of the somatostatin analogue RC160 , either in animals or in humans. In the present study, therefore, we evaluated the potential use of radiioiodinated RC-160 for somatostatin receptor scintigraphy. There was significantly higher uptake and specific binding in somatostatin receptor-positive organs, such as the pancreas, the adrenal and the anterior pituitary gland, of ${ }^{123} \mathrm{I}$ after administration of $\left[{ }^{123} \mathrm{I}-\mathrm{Tyr}^{3}\right]$ octreotide than after ${ }^{123} \mathrm{I}-\mathrm{RC}-160$.

In brain cortex of control rats we found at $4 \mathrm{~h}$ a low, but statistically significant specific binding of ${ }^{123} \mathrm{I}-\mathrm{RC}$ 160. However, this was caused by a very low amount of tracer $(0.0052 \%$ of injected dose per gram) in comparison with other somatostatin receptor-positive tissues, such as the pancreas $(0.21 \%$ of injected dose per gram). Since we found a significant difference between the uptake of radioactivity in saturated and non-saturated brain cortex, these data suggest that, in contrast to octreotide, RC-160 and radioiodinated $\mathrm{RC}-160$ are able to cross the blood-brain barrier, as has also been reported for cold RC-160 and radioiodinated RC-160 by Banks et al. [21, 24]. The presence of the C-terminal amino acid tryptophan in RC-160 (see Fig. 1) enhances the lipophilicity of the molecule, and this might also explain its increased blood-brain barrier permeability and reduced clearance from the tissues and blood.

During the first 30 min after the injection of ${ }^{123} I-R C$ 160 there was no statistically significant uptake in the tumour as measured by gamma camera scintigraphy, nor was there any after background correction. This finding is in contrast with the results of the experiments with [ $\left.{ }^{123} \mathrm{I}_{-} \mathrm{Tyr}^{3}\right]$ octreotide as described by Bakker et al. [6]. However, 30 min after the injection of ${ }^{123}$ I-RC-160, statistically significant specific binding in the isolated tumour was found. Since there is no significant difference between the uptake or specific binding after the injection of $\left.{ }^{[23} \mathrm{I}-\mathrm{Ty} \mathrm{r}^{3}\right]$ octreotide and ${ }^{123} \mathrm{I}-\mathrm{RC}-160$ in the isolated tumour at $30 \mathrm{~min}$, the relatively low tumour to blood ratio in these experiments is probably the reason for this discrepancy.

To conclude: ${ }^{123}$ I-RC-160 does not seem to have advantages over $\left[{ }^{123} \mathrm{I}-\mathrm{Tyr}^{3}\right]$ octreotide as a radiopharmaceutical for somatostatin-receptor scintigraphy, despite the fact that ${ }^{123}$ I-RC-160 shows specific high-affinity binding to various somatostatin receptor-positive organs. In contrast to radioiodinated $\left[\mathrm{Tyr}^{3}\right]$ octreotide and octreotide, which do not pass the blood-brain barrier, our experiments confirm that RC-160 and radioiodinated RC160 indeed do pass the blood-brain barrier. However, this occurs in low quantities, and consequently the application of radioiodinated RC-160 in nuclear medicine for visualizing somatostatin receptor-positive brain tumours with an intact blood-brain barrier is hampered. In comparison with $\left[{ }^{123} \mathrm{I}-\mathrm{Tyr}^{3}\right]$ octreotide, the main disadvantage of ${ }^{123} \mathrm{I}-\mathrm{RC}-160$ is its relatively low tumour to blood (background) ratio, implying poorer in vivo tumour detection.

Apart from the discussed data, it must be emphasized that several authors have reported that in comparison to octreotide, RC-160 has superior binding characteristics in some human tumours. Therefore, RC-160 and, in spite of its disadvantages, ${ }^{123} \mathrm{I}-\mathrm{RC}-160$ could open new diagnostic and/or therapeutic applications in patients bearing such tumours. Consequently, in analogy to the development of the indium-111 labelled [DTPA-DPhe ${ }^{1}$ ]octreotide analogue, ${ }^{111}$ In-labelled [DTPA-DPhe $\left.^{\mathrm{l}}\right] \mathrm{RC}-160$ is being prepared and investigated.

The authors wish to thank Dr. Wil Kort, Ineke Hekking-Weyma, Reno Mekes, Marcello Harms and Ina Loeve for their expert assistance during the experiments.

\section{References}

1. Reubi JC, Häcki WH, Lamberts SWJ. Hormone-producing gastrointestinal tumors contain a high density of somatostatin receptors. J Clin Endocrinol Metab 1987;65: 1127-1134

2. Reubi JC, Maurer R, von Werder K, Torhorst J, Klijn JG, Lamberts SWJ. Somatostatin receptors in human endocrine tumors. Cancer Res 1987;47: 551-558

3. Reubi JC, Lang W, Maurer R, Koper JW, Lamberts SWJ. Distribution and biochemical characterization of somatostatin receptors in tumors of the human central nervous system. Cancer Res 1987;47: 5758-5764

4. Reubi JC, Kvols LK, Waser B, Nagorney DM, Heitz PU, Charboneau JW, Reading CC, Moertel C. Detection of somatostatin receptors in surgical and percutaneous needle samples of carcinoids and islet cell carcinomas. Cancer Res 1990;50: 5969-5977

5. Krenning EP, Bakker WH, Breemann WAP, Koper JW, Kooij PPM, Ausema L, Lameris LS, Reubi JC, Lamberts SWJ. Localization of endocrine-related tumours with radioiodinated analogue of somatostatin. Lancet 1989;1: 242-244

6. Bakker WH, Krenning EP, Breemann WAP, Koper JW, Kooij PPM, Reubi JC, Klijn JG, Visser TJ, Doctor R, Lamberts 
SWJ. Receptor scintigraphy with a radioiodinated somatostatin analogue: radiolabelling, purification, biologic activity, and in vivo application in animals. $J$ Nucl Med 1990;31: 15011509

7. Bakker WH, Krenning EP, Breemann WAP, Kooij PPM, Reubi JC, Koper JW, De Jong M, Lameris JS, Visser TJ, Lamberts SWJ. In vivo use of a radioiodinated somatostatin analogue: dynamics, metabolism and binding to somatostatin receptorpositive tumours in man. $J$ Nucl Med 1991;32: 1184-1189

8. Lamberts SWJ, Hofland LJ, van Koetsveld PM, Reubi JC, Bruining HA, Bakker WH, Krenning EP. Parallel in vivo and in vitro detection of functional somatostatin receptors in human endocrine pancreatic cancers: consequences with regard to diagnosis, localization, and therapy. $J$ Clin Endocrinol Metab 1990; 71: 566-574

9. Lamberts SWJ, Bakker WH, Reubi JC, Krenning EP. Somatostatin-receptor imaging in the localization of endocrine tumors. N Engl J Med 1990;323: 1246-1249

10. Becker W, Marienhagen J, Scheubel R, Saptogino A, Bakker WH, Breeman WAP, Wolf F. Octreotide scintigraphy localizes somatostatin receptor-positive islet carcinomas. Eur $J \mathrm{Nucl}$ Med 1991;18: 924-927

11. Faglia G, Bazzani N, Spada A, Arioso M, Ambrosi B, Spinelli F, Sara R, Bonino C, Lungho F. In vivo detection of somatostatin receptors in patients with functionless pituitary adenomas by means of a radioiodinated analog of somatostatin ([123I] SDZ 204-090). J Clin Endocrinol Metab 1991;73: $850-856$

12. Ur E, Mather SJ, Bomanji J, Ellison D, Britton KE, Grossmann AB, Wass JAH, Besser GM. Pituitary imaging using a labelled somatostatin analogue in acromegaly, Clin Endocrinol 1992;36: 147-150

13. Reubi JC. New specific radioligand for one subpopulation of brain somatostatin receptors. Life Sci 1985;36: 1829-1836

14. Stkalovic G, Cai R-Z, Schally AV. Evaluation of receptors for somatostatin in various tumors using different analogs. $J$ Clin endocrinol Metab 1990;70: 661-669
15. Liebow C, Reilly C, Serrano M, Schally AV. Somatostatin analogues inhibit growth of pancreatic cancer by stimulating tyrosine phosphatase. Proc Natl Acad Sci USA 1989;86: 2003-2007

16. Pinski J, Milovanovic TY, Hamaoui A, Radulovic S, Cai R-Z, Schally AV. Biological activity and receptor binding characteristics to various human tumors of acetylated somatostatin receptors. Proc Soc Exp Biol Med 1992;200: 49-56

17. Poston GJ, Davis N, Schally AV, Schally AM, Gatiaburu J, Guillou PJ. Phase one B study of somatostatin receptor analogue RC-160 in treatment of patients with advanced exocrine pancreatic tumors [Abstract]. Digestion 1990;46: 170

18. Poston GJ, Schally AV, Schally AM, Guillou PJ. Phase one study on the use and tolerance of somatostatin receptor analogue RC-160 in the treatment of patients with advanted exocrine pancreatic tumors. Gut 1991;32: A342-A344

19. Reubi JC, Horrisberger U, Essed CE, Jeekel J, Klijn JGM, Lamberts SWJ. Absence of somatostatin receptors in human exocrine pancreatic adenocarcinomas. Gastroenterology 1988;95: 760-763

20. Maurer R, Reubi JC. Somatostatin receptors in the adrenal. Mol Cell Endocrinol 1986;45: 81-90

21. Banks WA, Schally AV, Barrera CM, Fasold BM, Durham DA, Csernus VA, Groot K, Ksatin A. Permeability of the murine blood-brain barrier to some octapeptide analogs of somatostatin. Proc Natl Acad Sci USA 1990;87: 6762-6766

22. Reubi JC, Häcki WH, Lamberts SWJ. Hormone-producing gastrointestinal tumors contain high density of somatostatin receptors. J Clin Endocrinol Metab 1986;63: 433-438

23. Oosterom R, Verleun T, Zuiderwijk J, Lamberts SWJ. Growth hormone secretion by cultured rat anterior pituitary cells. Effects of culture conditions and dexamethasone. Endocrinology 1983;113: 735-741

24. Banks WA, Kastin AJ, Radulovic S, Conley FK, Johnson DL, Schally AV. Selective uptake of the somatostatin analog RC160 across the blood-brain barrier of mice with KHT sarcomas. Anticancer Drugs 1992;3: 519-523 